\title{
THE SHAPE OF THE HUMAN LUMBAR VERTEBRAL CANAL
}

\author{
EDMUNDO ZARZUR*
}

\begin{abstract}
Literature on the anatomy of the human vertebral column characterizes the shape of the lumbar vertebral canal as triangular. The purpose of the present study was to determine the precise shape of the lumbar vertebral canal. Ten lumbar vertebral columns of adult male cadavers were dissected. Two transverse sections were performed in the third lumbar vertebra. One section was performed at the level of the lower border of the ligamenta flava, and the other section was performed at the level of the pedicles. The shape of the lumbar vertebral canal at the level of the pedicles tends to be oval or circular, whereas the shape of the lumbar vertebral canal at the level of the lower border of the ligamenta flava is triangular. Thus, the shape of the human lumbar vertebral canal is not exclusively triangular, as reported in the literature. It is related to the level of the transversal section performed on the lumbar vertebra. This finding should be taken into consideration among factors involved in the spread of solutions introduced into the epidural space.
\end{abstract}

KEY WORDS: vertebral column, shape of the lumbar vertebral canal, epidural space.

\section{A forma do canal vertebral lombar humano}

RESUMO - A literatura sobre a anatomia da coluna vertebral descreve como sendo triangular o formato do canal vertebral na região lombar. O objetivo deste estudo é determinar a real forma do canal da coluna vertebral lombar.Dez colunas vertebrais de cadáveres de homens adultos foram dissecadas. Dois cortes transversais foram executados na terceira vértebra lombar. Um corte foi feito no nível das bordas inferiores de dois ligamentos amarelos vizinhos e o outro corte foi transversal, no nível dos pedículos. A forma do canal vertebral variou: no nível dos pedículos ela tende a ser oval ou circular e junto às bordas inferiores dos ligamentos amarelos passa a ser triangular. Portanto, a forma do canal vertebral lombar não ế somente triangular; ela depende do nível em que se faz o corte transversal da vértebra. Estes achados devem ser levados em consideraçāo entre os fatores envolvidos na difusāo das soluçōes introduzidas no espaço peridural.

PALAVRAS-CHAVE: coluna vertebral, forma do canal vertebral lombar, espaço epidural.

Several literature reports characterize the shape of the human lumbar vertebral canal as being triangular ${ }^{1,2,7.8-10}$. This does not seem to be always the case ${ }^{4,11}$. The present study was undertaken with the objective of gaining a better understanding of the anatomy of the human vertebral column and particularly the shape of the lumbar vertebral canal. The purpose of the present study was to determine the precise shape of the lumbar vertebral canal and its relations with the cylindrical dural sac. The findings may add some knowledge about the factors which can affect the diffusion of solutions introduced into the lumbar epidural space.

This study was carried out at the Department of Surgery (Clinical Anatomy Branch) of the University of São Paulo Medical School, São Paulo and it was approved by the Committee on Human Ethics and Research: *M.D. This investigation has been partially presented in the First Pan American Symposium on Regional Anesthesia, São Paulo, Brazil in March 4-6, 1993. Aceite: 16-abril-1996. 


\section{MATERIAL AND METHODS}

Ten adult male cadavers preserved in formalin were utilized. Careful dissections were performed on all cadavers in which the soft tissues had been made fairly stiff by formalin. The lumbar segments of the vertebral columns were removed in block. All the superficial tissues were removed by dissection except the psoas muscle bilaterally ${ }^{10}$. Two transverse sections through the same third lumbar vertebra were made employing a bandsaw. One section was performed exactly at the lower border of the ligamenta flava and the other section was performed at the level of the vertebral pedicles. The mid-sagittal diameter of the lumbar canal was measured with a metric ruler graded in millimeters. All third lumbar vertebra of all 10 samples were photographically documented after dissection was completed.

\section{RESULTS}

The main findings of this study are the following:

The shape of the lumbar vertebral canal at the level of the vertebral pedicles tends to be oval or circular. At this level the lumbar vertebral canal is entirely surrounded by bony structures represented anteriorly by the posterior aspect of the vertebral body and posterolaterally by the vertebral pedicles and laminae. At this precise level, the mid-sagittal diameter of the vertebral canal measures 13 millimeters in average (Fig 1).

At the lower border of the ligamenta flava, the shape of the vertebral canal is triangular and the mid-sagittal diameter of the vertebral canal measures 22 millimeters in average (Fig 2). These shapes are representative of all lumbar vertebrae.

Figure 2 shows the triangular shape of the lumbar vertebral canal, the circular dural sac, the ligamenta flava, the intervertebral foramen and both psoas muscle. The soft tissues have been made

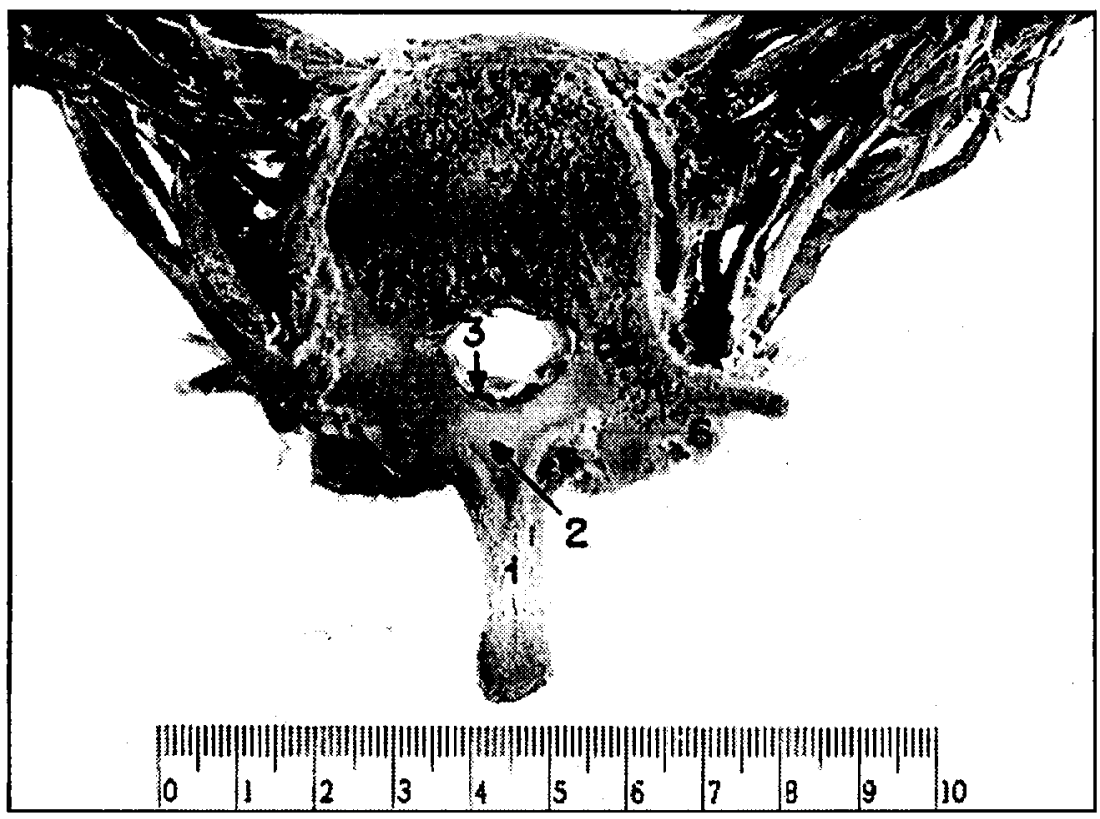

Fig 1. Transversal section through the pedicles of the third lumbar vertebra showing the circular shape of the lumbar vertebral canal: 1, spinous process; 2, vertebral lamina; 3, dura mater in contact with the vertebral canal wall; 4 , vein; 5 , vertebral body; 6, transverse process; 7, psoas muscle; 8 , vertebral pedicle. 


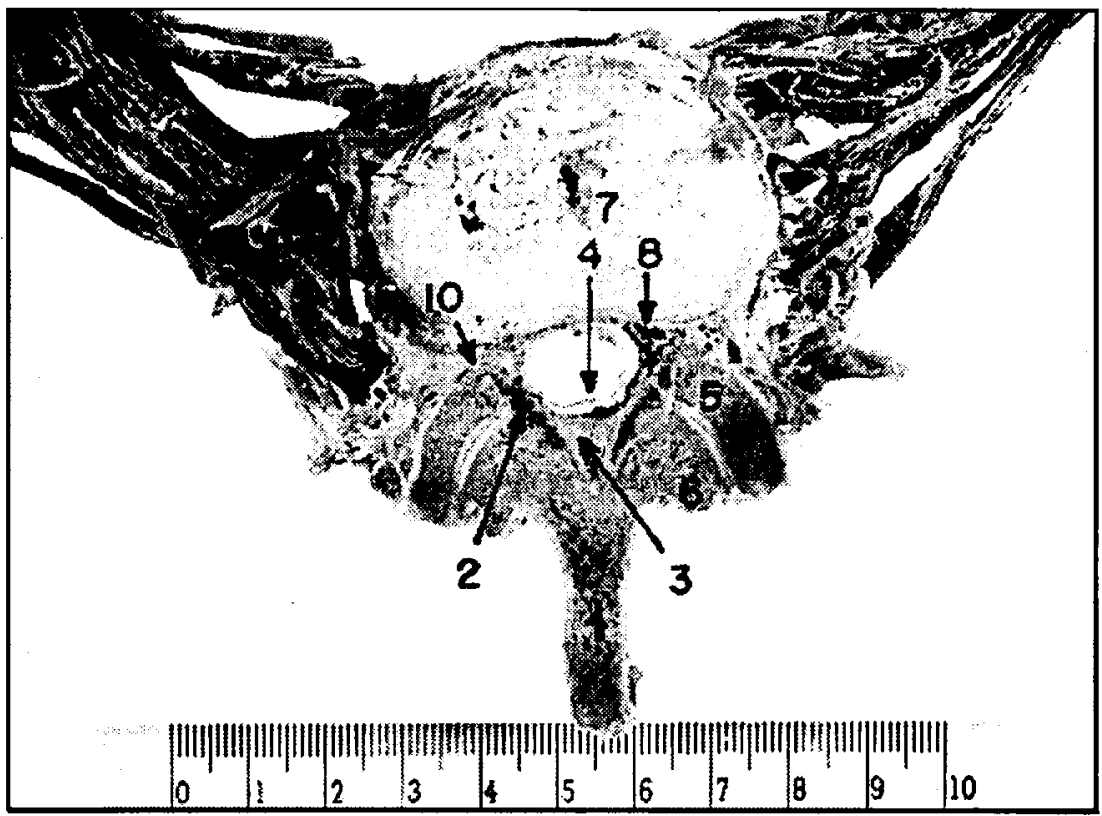

Fig 2. Transverse section of the same third lumbar vertebra though the lower border of the ligamenta flava showing the triangular shape of the lumbar vertebral canal: 1, spinous process; 2, ligamentum flavum; 3, epidural space (posterior compartment); 4, dura mater; 5, superior articular process; 6, inferior articular process; 7, intervertebral disc; 8, vein; 9, psoas muscle.

fairly stiff by formalin. The internal surfaces of the ligamenta flava are separated from the dura mater by the triangular epidural space (posterior compartment).

\section{DISCUSSION}

In order to interpret the computerized tomography and nuclear magnetic resonance imaging, a comprehensive knowledge of the vertebral canal anatomy is necessary. In order to allow a clear understanding on the anatomical relationship between the dural sac with the wall of the lumbar vertebral canal, careful dissections were performed in cadavers in which the soft tissues (the dural sac, ligamenta flava and the epidural fat) had been made fairly stiff by formalin. The skeletal shape of the lumbar vertebra is not affected by the formalin. The present findings are supported by observations using computerized tomography images and by previous anatomical studies ${ }^{4.11}$.

The cylindrical shape of the dural sac and the two different shapes of the lumbar vertebral canal may account for the partition of the epidural space in compartments. At the level of the vertebral pedicles, the epidural space is empty because the cylindrical dural sac is in direct contact with the vertebral canal wall which is circular at this level (Fig 1). At the lower border of the ligamenta flava, the shape of the lumbar vertebral canal is triangular and the epidural space has contents distributed in three compartments, one posterior and two lateral compartments in each lumbar segment (Fig 2). The posterior compartment is triangular and it contains fat, whereas the lateral compartments contain nerve roots, fat, blood and lymphatic vessels.

The posterior and lateral compartments are circumferentially and longitudinally separated by areas (at the level of the vertebral pedicles) where the cylindrical dural sac is in direct contact with the wall of the lumbar vertebral canal and with the ligamenta flava. In these areas the epidural space is empty and the dura mater exerts different degrees of pressure on the canal wall, depending on the 
local cerebrospinal fluid (CSF) pressure. It has been demonstrated that the lumbar epidural pressure is positive and it bears a clear relationship with the CSF pressure ${ }^{5,6}$.

This CSF pressure mantains the dura mater opposed to the vertebral canal wall. Although this fact may affect the diffusion of a solution introduced into the posterior epidural compartment, solutions injected into the epidural space can pass from one compartment to another because the dura mater is not attached to the canal wall. In the sitting position, the higher CSF pressure stretches the lumbar dura mater occluding the epidural space at the vertebral pedicles level, thus restricting the caudal spread of the injected solutions. In conclusion, the shape of the human lumbar vertebral canal is not exclusively triangular. It is dependent on the level of the transverse section performed on the lumbar vertebra. This fact must be taken into account when studying the factors affecting the diffusion of solutions introduced into the lumbar epidural space.

Acknowledgments - The author is thankful to Carlos Pereira Parsloe and Dr. Flávio Alóe for their helpful suggestions and for reviewing the manuscript.

\section{REFERENCES}

1. Dogliotti AM. Trattado di anestesiu. Torino: Unione Tipografica Editrice Torinese, 1935:428.

2. Gaynor A. The lumbar epidural region: anatomy and approach. In Reynolds F. Epidural and sipnal blockade in obstetrics. London: Baillière Tindall WB Saunders, 1990:3-18.

3. Hogan QH. Lumbar epidural anatomy: a new look by cryomicrotome section. Anesthesiology 1991;75:767-775.

4. Postacchini F, Pezzeri G, Montanaro A, Natali G. Computerised tomography in lumbar stenosis: a preliminary report. J Bone Joint Surg 1980;62-B:78-82.

5. Shah JL. Influence of cerebrospinal fluid on epidural pressure Anaesthesiu 1981;36:627-631.

6. Shah JL. Positive lumbar extradural space pressure. Br J Anaesth 1994;73:309-314.

7. Spalteholz W. Atlas de anatomia humana. Barcelona: Labor, 1972:99.

8. Testut L. Traité d'anatomie humaine. Paris: Libraire Octave Doin, 1921:96.

9. Warwick R, Williams PL. Gray's anatomy. Ed35. Great Britain: Jarrold \& Sons, 1973:240.

10. Zarzur E. Anatomic studies of the human Jumbar ligamentum flavum. Anesth Analg 1984;63:499-502.

11. Zarzur E. The shape of the human lumbar vertebral canal. Reg Anesth 1993;18(Suppl): 1S27. 